\title{
Carbon Dioxide Capture and Storage Potential of Mahogany (Swietenia macrophylla) Saplings
}

\author{
Jerry B. Superales
}

\begin{abstract}
In the light of increasing fears about climate change, green house gas mitigation is one of the today's major concerns. Carbon capture and storage are the options in the reduction of $\mathrm{CO}_{2}$ emission intensity. Trees are among the most important and common sinks for atmospheric carbon. The carbon storage potential of Mahogany (Sweitenia macrophylla) sapling has to be elucidated to shed light on the contribution of this sapling in greenhouse reduction. The study aimed to assess the aboveground standing biomass of the species, $\mathrm{CO}_{2}$ capture and $C$ storage potential of the leaves, bark and wood of this species. Allometric equation was used to calculate the above ground biomass which served as basis in the calculation of $\mathrm{g} \mathrm{C}$ stored into a ratio of $\mathrm{CO}_{2}(\mathrm{~g})$ captured by the species. The result showed that the wood of the samples had an average biomass of $268.26 \mathrm{~g}$ and captured more $\mathrm{CO}_{2}(16.244 \mathrm{~g})$ compared to the leaves $(12.111 \mathrm{~g})$ and bark (5.934 g). Each sample species have accounted storage of $4.458 \mathrm{~g} \mathrm{C}$ in the wood, $3.325 \mathrm{~g} \mathrm{C}$ in the leaves and $1.162 \mathrm{~g} \mathrm{C}$ in the bark. The aboveground biomass of each sapling has potentially captured a total of $34.29 \mathrm{gCO}_{2}$ from the atmosphere. The grams of $\mathrm{C}$ stored to the biomass of the saplings which largely contained in the wood, small amount in the leaves and least in the bark.
\end{abstract}

Index Terms-Biomass, carbon dioxide capture, storage potential, Swietenia macrophylla.

\section{INTRODUCTION}

Global warming is among the most dreaded problems of this millennium which just represents one aspect of climate change. The global warming is caused mostly by increasing concentrations of greenhouse gases in the atmosphere resulting to changes in climate pattern. Greenhouse gases (GHGs) which are primarily carbon dioxide, methane, nitrous oxide and others has influenced the earth's climate system.

Reference [1] reported that the concentration of atmospheric $\mathrm{CO}_{2}$ has increased from $278 \mathrm{ppm}$ in the pre-industrial era (1970) to $379 \mathrm{ppm}$ in 2005 with an average increase of 1.9 ppm per year; largely attributing to human activities like burning of fossil fuels, land use change and deforestation especially in the tropical forests. The report has also precisely predicted an increase of $1.8{ }^{0} \mathrm{C}$ in global temperature at the end of this century. Thus, the provision of article 4 which states that necessitates on preventing and minimizing climate change by limiting anthropogenic emissions of greenhouse and protecting and enhancing the greenhouse gas sinks and reservoirs [2]. Reference [3], in

Manuscript received June 15, 2015; revised September 18, 2015. This work was supported by the Commission on Higher Education-Philippines through its financial support program for paper presentation in International Conferences.

J. B. Superales is with the J. H. Cerilles State College, Mati, San Miguel, 7029 Zamboanga del Sur, Philippines (e-mail: superjerry27@gmail.com). mitigating climate change, the society should immediately take significant steps to reduce greenhouse gas emissions through energy conservation and improved efficiency. Forest can also play an important role in mitigating climate change by naturally taking carbon out of the atmosphere, thereby reducing the impact of $\mathrm{CO}_{2}$ emissions. Higher temperatures, changes in precipitation patterns, and more frequent and severe disturbances are all the projected result of increased levels of atmospheric carbon dioxide.

Major studies indicate that forestry activity is an important strategy for green house gas reduction and climate change mitigation. Tree is an important route for $\mathrm{CO}_{2}$ to move from atmospheric gas to solid form. This carbon is sequestered, primarily in the new wood and increase soil organic matter that accompanies forest growth [4]. Carbon is stored in tree biomass and in soil that helps protect natural carbon sinks through the improvement of land productivity and the provision of forest products on agricultural lands [5].

Trees accumulate more carbon dioxide than the atmosphere and play an important role in global carbon cycle. With the increasing concern for rising $\mathrm{CO}_{2}$ concentrations, its role on the long term carbon pool for assimilation of atmospheric $\mathrm{CO}_{2}$ is being realized. $\mathrm{CO}_{2}$ is taken up from the atmosphere during the growing season of vegetation and stored as plant biomass [6]. The fundamental science of carbon sinks is well understood-biological growth binds in the cells of trees and other plants while releasing oxygen into the atmosphere through the process of photosynthesis. Trees sinks have the potential to play a valuable role in carbon sequestration. Although sinks are only a partial solution to anticipated global warming, they do appear to have the potential to sequester 10 to $20 \%$ of the anticipated build-up atmospheric carbon over the next 50 years [7].

Despite the widespread recognition of agroforestry for carbon storage there is still lack of quantitative data on specific systems and their contribution to climate change mitigation [8] particularly on the $\mathrm{C}$ stocks of nursery sapling species. Presently, there are no actual baseline data on carbon stocks of Mahogany sapling and can be found in literature. In consonance with the concerted efforts of the local community in promoting the reduction of $\mathrm{CO}_{2}$ emissions, the conduct of this type of study is imperative. The main aim of this investigation is to calculate the properties of the aboveground standing biomass of Mahogany (Swietenia macrophylla) sapling in terms of moisture content, dry matter, and organic matter present in its wood, leaves and bark. Further, the study has to estimate the amount of carbon stored in the wood and foliage of the samples and calculate its carbon dioxide ratio captured by the said parameters from the atmosphere.

The results of the study may show the significance of local mahogany nurseries in reducing carbon dioxide from the 
atmosphere. This may also generate information and create ideas in modeling empirical and ecological phenomena on carbon capture and storage of mahogany saplings which may be used by other researchers in conducting relevant studies and academic exercises.

\section{MethodOLOGY}

\section{A. Collection of Samples}

In-vivo experimentation was conducted in the laboratory using thirty (30) saplings of Mahogany (Swietenia macrophylla) as samples with an average height of $163 \mathrm{~cm}$. These were collected from the wild or naturally grown in the field with almost the same in height. These were randomly divided equally into five sampling batches to contain 6 samples. Three (3) chunks from three (3) different region of the stem per sapling were selected approximately $1 \times 5$ inches dimension; barks were peeled off from these regions. A cut of $1 \times 5$ inches in dimension was taken from each of the selected region. These were replicated in all sampling batches. All samples were weighed using analytical balance to get the fresh weight. Each chunk of sample was placed in a graduated cylinder to measure its volume using the water displacement method. The stem and foliage density of each sample was determined by obtaining weight-volume measurements. The total number of leaf in each sample sapling was estimated by direct counting. The volume stand of each sapling was calculated upon measuring directly its diameter at the basal area using a tape and height using a meter stick.

\section{B. Calculation of Biomass and Properties of the Sample}

The biomass properties of the wood, leaf and bark were calculated using the following basic formula [9] on the basis of fresh and dry weights of the samples:

$$
\text { Moisture Content }(\%)=\frac{\text { Fresh Wt }- \text { Dry Wt }(\text { Oven })}{\text { Fresh Wt }} \times 100
$$

$$
\text { OM Content }(\%)=\frac{\text { Dry Wt }- \text { Ash Wt (furnace })}{\text { Dry Wt }} \times 100
$$

$$
\operatorname{DMC}(\%)=\frac{\text { Dry Wt } \times 100}{\text { Fresh Wt }}
$$

The wood density of the sample was calculated using the formula [10].

$$
W D=\frac{S D W c}{S V}
$$

where:

$$
\begin{aligned}
& W D=\text { the wood density }\left(\mathrm{g} \cdot \mathrm{cm}^{-1}\right) \\
& S D W c=\text { the dry weight of sample cube } \\
& S V=\text { the volume of sample cube }
\end{aligned}
$$

The allometric equation was used to calculate the sapling aboveground biomass [11]. The stand volume of each sapling was computed using the following formula:

$$
\text { Stand Volume }=1 / 3 \pi \mathrm{r}^{2}(\mathrm{~h})
$$

where:

$$
\pi=3.1416
$$

$r^{2}=$ diameter at the basal area and $\mathrm{h}=$ height

The biomass of the stand volume was calculated based on the density $\left(\mathrm{g} / \mathrm{cm}^{3}\right)$ of the sample (i.e. wood) multiplied to the stand volume $\left(\mathrm{cm}^{3}\right)$ of the sapling. The total aboveground biomass was obtained after adding-up the biomass of the thirty (30) samplings considering the entire five sampling periods. The foliage biomass was calculated upon multiplying the average dry weight of the sample to the total number of stalk per sapling. The ratio and proportion of the wood biomass and the foliage of the mahogany sapling was estimated by dividing the mean biomass of the wood to the mean biomass of the leaves. The amount of carbon in the sapling was obtained by relating it to the stand volume biomass of the sapling and the OM content of the samples.

\section{Laboratory Analyses}

The collected samples were weighed and subjected for oven drying at $110 \pm 2{ }^{\circ} \mathrm{C}$ within 24 hours as suggested [12] Mechanical oven was used for this experiment. Oven dried samples were weighed again to calculate the moisture content and dry matter content using digital weighing scale. These samples were placed in the improvised furnace for combustion. After burning, the ash was weighed to get the precise weight of the ash per sample. The organic matter content of the wood, leaves and bark were then computed.

The value of carbon content in the organic matter can be computed following the estimate where the percentage of carbon from the organic matter (97.75\%) is 48.5 [13]. Hence, the value of 0.496 was known through the percentage of carbon divided by the organic matter. To estimate the carbon dioxide stored by each sapling, the weight of the carbon in a sapling is multiplied with 3.6663 s since the atomic weight of $\mathrm{C}$ is 12.001115 , atomic weight of oxygen is 15.9994 and the weight of $\mathrm{CO}_{2}$ is $\mathrm{C}+(2 \times \mathrm{O})=43.999915$, thus the ratio of $\mathrm{CO}_{2}$ to $\mathrm{C}$ 43.999919: $12.001115=3.6663$. Reference [14] equation in estimating tree biomass was used as basis in calculating the $\mathrm{C}$ stored in sapling parts (bark, leaves, wood). Carbon stored was calculated using the following formula: $\mathrm{C}$ stored $\left(\mathrm{gC} \mathrm{cm}^{-1}\right)=$ Sapling-part biomass density $* \mathrm{C}$ content

\section{RESULTS AND DISCUSSION}

The percents MC, DM, and OM from the stem, bark, and leaves of mahogany sample saplings are illustrated in Table I. The average MC of the sapling ranges from $44-67 \%$ with DM content of $32.39-55.66 \%$ and OM of $43.55-48.21 \%$. Among the three (3) parameters (wood, bark and leaves) considered in the study, the bark appeared to have the highest MC $(67.38 \%)$ followed by leaves $(62.62 \%)$ and the wood $(43.74 \%)$ contained the least. In terms of percent OM content of the saplings, the wood has contained of about $48.21 \%$, followed by the bark $(47.004 \%)$, then the leaves $(43.55 \%)$. The percent DM content of the samples indicated $55.66 \%$ in the wood, $47.43 \%$ in the leaves and $32.39 \%$ in the bark.

The aboveground biomass of the each sample was $46.25 \%$ of the total weight of each sapling stand. This result is similar with the study of [13] that about $47-50 \%$ of the dry matter is the $\mathrm{C}$ content in most wood which is used to estimate the value of $\mathrm{C}$ in the study. The average ratio of biomass between the 
wood and the leaf is $1.47: 1$ as illustrated in Table II. The above calculations depend on sample sapling's structure i.e. density of samples (number of samples considered), diameter, basal area, height, and age. Reference [15] as cited by reference [16] also noted that the biomass of trees is greatly influenced by two important variables like the diameter-at-breast height and the height itself.

TABLE I: ABOVE GROUND BIOMASS OF MAHOGANY SAPLINGS

\begin{tabular}{|c|c|c|c|c|c|c|c|c|c|}
\hline & \multicolumn{3}{|c|}{ Bark } & \multicolumn{3}{|c|}{ Leaves } & \multicolumn{3}{|c|}{ Wood } \\
\hline $\begin{array}{l}\text { Sampling } \\
\text { Period }\end{array}$ & $\% \mathrm{MC} *$ & \%DM* & $\% \mathrm{OM}^{* *}$ & $\% \mathrm{MC}^{*}$ & \%DM* & $\% \mathrm{OM}^{* *}$ & \%МC* & \%DM* & $\% \mathrm{OM}^{*}$ \\
\hline 1 & 71.21 & 28.08 & 51.13 & 59.93 & 40.08 & 37.21 & 45.25 & 54.87 & 46.23 \\
\hline 2 & 68.50 & 31.50 & 39.13 & 67.4 & 32.53 & 50.73 & 43.75 & 56.14 & 56.27 \\
\hline 3 & 69.30 & 30.70 & 51.42 & 65.97 & 34.26 & 39.56 & 44.71 & 55.29 & 36.99 \\
\hline 4 & 64.31 & 35.69 & 47.73 & 59.24 & 40.76 & 44.08 & 44.22 & 55.78 & 46.78 \\
\hline 5 & 63.57 & 35.26 & 45.61 & 60.50 & 39.50 & 46.17 & 43.38 & 56.22 & 54.79 \\
\hline Total & 336.89 & 161.95 & 235.02 & 313.11 & 187.13 & 217.17 & 218.71 & 278.30 & 241.06 \\
\hline Mean & $67.38^{* * * *}$ & $32.39^{* * * *}$ & $47.00^{* * * *}$ & $62.62^{* * * *}$ & $37.43^{* * * *}$ & $43.55^{* * * *}$ & $43.74^{* * * *}$ & $55.66^{* * *}$ & $48.21^{* * * *}$ \\
\hline
\end{tabular}

* fresh weight basis

** dry weight basis

***average value for \% MC, \%DM, and \%OM based on three (3) samples each from bark, leaves, and wood in a given sampling

The carbon dioxide captured by the wood, bark and leaves of the sapling has the total amount of $1028.69 \mathrm{~g}(\approx 1.03 \mathrm{~kg})$ as presented in Table III. Among the parts of the sapling considered, the wood have the highest amount of $\mathrm{CO}_{2}$ uptake which is equivalent to $487.32 \mathrm{~g}$ with an average of $16.24 \mathrm{~g} \approx$ $0.01624 \mathrm{~kg}$ followed by the leaves $(12.11 \mathrm{~g} \approx 0.1211 \mathrm{~kg})$ and the bark $(5.934 \mathrm{~g} \approx 0.05934 \mathrm{~kg})$. The amount of $\mathrm{C}$ stored by the sapling is about $27 \%$ of the total $\mathrm{CO}_{2}$ captured or $282.15 \mathrm{~g}$. The wood, leaves and the bark have stored $133.74 \mathrm{~g}, 99.76 \mathrm{~g}$ and $48.56 \mathrm{~g} \mathrm{C}$ accordingly. Reference [17] on this study, this figure is $18 \%$ lower than the default value $(45 \%)$ used to determine the carbon stored in tree biomass or the average carbon content of wood collected from secondary forests in the several locations of the country. The estimated carbon stocks were based on the tree biomass using allometric equations [16].

TABLE II: PROPORTION (\%) OF THE TRUNK AND FOLIAGE BIOMASS

\begin{tabular}{lcccccc}
\hline $\begin{array}{l}\text { Sampling Number of } \\
\text { FB\% }\end{array}$ & Dia & No. of stalk per & Wood & Foliage & SB\% \\
$\begin{array}{l}\text { Period } \\
\text { Total }\end{array}$ & Sapling & $(\mathrm{cm})$ & sapling & Biomass (g) & Biomass (g) & Total \\
\hline \multicolumn{7}{r}{} \\
& Ave & Ave & Total & \multicolumn{2}{c}{ Total } \\
\hline
\end{tabular}

\begin{tabular}{|c|c|c|c|c|c|c|}
\hline $\begin{array}{c}1 \\
40.59\end{array}$ & 6 & 1.05 & & & & \\
\hline $\begin{array}{c}2 \\
30.15\end{array}$ & 6 & 0.90 & 8.33 & 1772.46 & 765.00 & 69.85 \\
\hline $\begin{array}{c}3 \\
44.42\end{array}$ & 6 & 0.83 & 9.33 & 72.18 & 856.80 & 55.58 \\
\hline $\begin{array}{c}48.84 \\
5 \\
39.65\end{array}$ & 6 & 1.01 & 11.83 & 1653.33 & 108 & \\
\hline $\begin{array}{c}\text { Total } \\
203.65 \\
\end{array}$ & 30 & & & 8047.79 & 5462.10 & 296.27 \\
\hline $\begin{array}{l}\text { Mean* } \\
\text { Ave. }(\%) \\
40.78 * *\end{array}$ & & & & 268.2 & 182. & $59.25 * *$ \\
\hline
\end{tabular}

SB- Wood biomass

FB- Foliage biomass

*-per sapling basis

**-per sampling basis

This data implies that even if how young the sapling is, it still absorbs considerable amount of carbon dioxide from the atmosphere that contribute mitigating the global warming. Otherwise, trees accumulate more $\mathrm{CO}_{2}$ than the atmosphere and play important role in global carbon cycle [6]. There are growing concerns on the role of trees in the community for managing atmospheric carbon sequestration. Many researchers were able to come-up an activities that lead to reduction in $\mathrm{CO}_{2}$ from various sources. Reference [18], the management activities or practices at community forest has helped sink more carbon. Therefore, community tree growing plays an important role in securing livelihood and providing environmental benefits to the local communities. This can be considered as part of the carbon emission reduction efforts of the local community.

TABLE III: CARBON DIOXIDE CAPTURED BY THE MAHOGANY SAPLINGS

\begin{tabular}{|c|c|c|c|c|}
\hline \multicolumn{5}{|c|}{$(N=30)$} \\
\hline \multirow[t]{2}{*}{ Plant Part } & \multicolumn{2}{|c|}{ g Carbon } & \multicolumn{2}{|c|}{ g Carbon dioxide } \\
\hline & Average & Total & Average & Total \\
\hline Wood & 22.30 & 133.74 & 80.51 & 487.32 \\
\hline Bark & 8.10 & 48.56 & 29.68 & 178.03 \\
\hline Leaves & 16.64 & 99.76 & 50.56 & 363.34 \\
\hline Total & 47.04 & 282.06 & 160.75 & 1028.69 \\
\hline Mean & 1.568 & 9.402 & 5.358 & 34.29 \\
\hline
\end{tabular}

\section{CONCLUSIONS}

The bark of the Mahogany saplings has the highest moisture content compared to the leaves and the wood which contained the least. However, the wood of each sample sapling has the highest estimate on \% OM followed by the bark and the leaves. In the study, the wood has the highest \% $\mathrm{DM}$ and proportionally captured $\mathrm{CO}_{2}$ more than the leaves and bark. This means that the raw materials $\left(\mathrm{CO}_{2}\right)$ for photosynthesis are mostly stored in the wood among the other parameters considered in sample species. The estimated total $\mathrm{CO}_{2}$ stored by the sample saplings is more than $1 \mathrm{~kg}$. To speak, a $10 \times 10 \mathrm{~m}$ of mahogany plant nursery consisting 160 saplings with an average height of $163 \mathrm{~cm}$ could approximately capture about 5,486.35 $\mathrm{g} \mathrm{CO}_{2}$ which result to reduction of the concentration of these gases from the atmosphere. Apparently, mahogany saplings potentially stored $\mathrm{C}$ tantamount to $1,504.329 \mathrm{~g}$ or about $2 \mathrm{~kg}$.

\section{ACKNOWLEDGMENT}

The author is grateful to the Commission on Higher 
Education (CHEd) for the travel grant to present this paper to an International Conference. He is deeply indebted to Ms. Mary Mae L. Bayno, Ms. Sheryll A. Carbaquil, and Ms. Joy L. Opelentisima who undertook most of the field and laboratory works in the conduct of the study.

\section{REFERENCES}

[1] IPCC, "Summary for policy makers," Climate Change: The Physical Science Basis, Cambridge University Press, 2007.

[1] The Kyoto Protocol to the United Nations Framework on Climate Change, United Nations Framework Convention on Climate Change (UNFCCC)/FCCC/1997, July 1998.

[2] R. Perschel, A. Evans, and M. Summers. (August 2007). Climate change, carbon and the forests of the Northeast. Forest Guild. [Online]. p. 47. Available: http://www. forestguild.org/publication/research

[3] H. Yang et al., "Progress in carbon dioxide separation and capture: A review," Journal of Environmental Sciences, vol. 20, no. 1, pp. 14-27, 2008.

[4] A. Albrecht and S. Kandji. "Carbon sequestration in tropical agroforestry systems," Agriculture, Ecosystems, and Environment, vol. 99, pp. 15-27, 2003.

[5] C. J. Losi, T. G. Siccama, R. Condit, and J. E. Morales, "Analysis of alternative methods for estimating carbon stock in young tropical plantations," Forest Ecology and Management, vol. 184, no. 1-3, pp. 355-368, 2003.

[6] R. Sedjo, R. Mendelsohn, B. Sohngen. (July 1998). The effectiveness of forest carbon sequestration strategies with system-wide adjustments. [Online]. Available: http://www.citeseerx.ist.psu.edu/viewdoc/download

[7] M. M. Labata, E. C. Aranico, A. E. C. Tabaranza, J. H. P. Patricio, and R. F. Amarado, "Carbon stock assessment of three selected agroforestry systems in Bukidnon, Philippines," Advances in Environmental Science, vol. 4, no. 1, pp. 5-11, 2012.

[8] S. Brown, Estimating Biomass \& Biomass Change of Tropical Forests: A Primer, FAO Forestry Paper, FAO, Rome, 1997.

[9] S. Brown, "Measuring carbon in forests: Current status and future challenges," Environmental Pollution, vol. 116, no. 3, pp. 363-372, 2002.

[10] M. N. Henry, C, Picard, R. J. Trotta, R. Manlay, R. Valentini, M. Bernoux, and L. Saint-Andre, "Estimating tree biomass of sub-Saharan African forests: A review of available allometric equations," Silva Fennica, vol. 3B, pp. 477-569, 2011.
[11] T. G. Malczewski, "Wood carbon content of the species in Eastern China: Interspecific variability and importance of the volatile fraction," Journal of Environment, 2007.

[12] K. W. Ragland, D. J. Aerts, and A. J. Baker, Properties of Wood for Combustion Analysis, 1991.

[13] R. N. Banaticla, R. F, Sales, and R. D. Lasco., "Biomass equations for tropical tree plantation species using secondary data from the Philippines", Philippines, July 2004.

[14] L. M. Tandug, M. V. Lantig Jr., P. A. Umali, and N. L. M. M. Lantican, "Allometry of above ground biomass and carbon content of forest tree species," Canopy International, vol. 36, pp. 1-6, 2010.

[15] R. A. Marin, A. M. Tulod, J. G. Opiso, F. M. Acma, R. R. Baldo, F. C Coritico, and V. B. Amoroso, "Carbon storage potential of four long term ecological research (LTER) sites in Mindanao, Philippines based on forest inventory data," Asia Life Sciences, vol. 24, no. 1, pp 277-284.

[16] R. D. Lasco and F. B. Pulhin, "Forest-land-use change in the Philippines and climate change mitigation: Mitigation and adaptation strategies," Global Change Journal, vol. 5, pp. 81-97, 2000.

[17] B. S. Karky. "The economics of reducing emmissions from community managed forests in Nepal Himalaya," Ph.D. dissertation, University of Twente, The Netherlands, 2008.

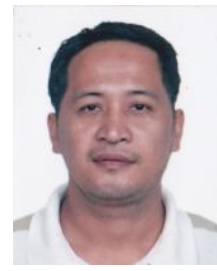

Jerry B. Superales is a professor in a State-Run Higher Education Institution in the Philippines, the J H. Cerilles State College, Mati, San Miguel, Zamboanga del Sur. He worked in the government service for 20 years. He held various academic and administrative designations aside from having solid technical experience and background in social and environment research. $\mathrm{He}$ is highly motivated, optimistic and with keen insights. He has proven research team leader and outcome-based oriented with broad experience in limnological techniques for water quality assessment, mangrove habitat/ ecosystem research and relevant social science researches. He has solid planning and organizational skills in coordinating and implementing research projects from inception stage through completion as well as presentations of results to relevan international conferences/fora and publications to reputable peer-reviewed scientific journals. Attended various local, national and international conferences, seminars and workshops related to the field in agriculture, natural resources, environment and social sciences. He is well disciplined and diligent with proven ability to manage multiple assignments and research team efficiently under extreme pressure while meeting tight deadline schedules. 